九州大学学術情報リポジトリ

Kyushu University Institutional Repository

Effect of vaccines on the production of bactericidal activity and hemolymph lysozyme level in the silkworm (Bombyx mori L.)

Kawabata, Takeshi

https://doi.org/10.5109/22812

出版情報：九州大学大学院農学研究院紀要. 16 (4)，pp.511-517，1971-11. Kyushu University バージョン：

権利関係 : 


\title{
Effect of vaccines on the production of bactericidal activity and hemolymph lysozyme level in the silkworm (Bombyx mori L.)
}

\section{Takeshi KAWARABATA}

\begin{abstract}
The production of bactericidal activity and serum lysozyme level in the silkworm hemolymph were studied. Bacterial vaccines enhanced significantly the bactericidal activity in the pupal hemolymph by hemocoel. However, the serum lysozyme level were not affected by the vaccination. All attempts to increase serum lysozyme level by various vaccines were unsuccessful.
\end{abstract}

\section{Introduction}

Presence of antibacterial substances in an immunized hemolymph of insects have been reported by early investigators (Glaser, 1918, Zernoff, 1931). Antibacterial activity without lysis of the organisms was present in normal and immune sera of several species of Lepidoptera (Briggs, 1958, Stephens, 1962). Gingrich (1964) reported serum from milkweed bugs immunized with Pseudomonas aeruginosa posessed bacteriolytic activity against homologus antigen. Hink \& Briggs (1968) reported the bactericidal factors are present in Galleria mellonella larva. The bactericidal substances in Galleria were considered to be relatively low molecular weight, heat stable, and non-protein in nature (Stephens \& Marshall, 1962, Hink \& Briggs, 1968). The presence of serum lysozyme and its relation to non-specific bactericidal action in vertebrate sera have been studied (Skarnes \& Watson, 1957, Salton, 1957, Schwab \& Reevs, 1966). The aim of this paper is to further our knowledge of non-specific bactericidal action and the production of bacterial inhibitory factors in an insect hemolymph. Bactericidal activity and serum lysozyme level in normal and immunized silkworm pupal sera are investigated.

\section{Materials and Methods}

Silkworm strain: Shûkô $\times$ Ryûhaku, Taihei $\times$ Chôan were used for experiments. 
Silkworm pupae - The silkworm pupae were stored at $4^{\circ} \mathrm{C}$, soon after pupation. Before use, pupae were kept at $27^{\circ} \mathrm{C}$ for $12 \mathrm{hrs}$. All pupae were used within a month after the time of pupation.

Preparation of bacterial vaccines : Pseudomonas aeruginosa PS 14, Serratia marcescens, Staphylococcus aureus $209 \mathrm{P}$, Bacillus sotto Ishiwata were used as bacterial vaccines. The bacteria were grown on nutrient agar slants for $24 \mathrm{hrs}$. at $37^{\circ} \mathrm{C}$, suspended and washed twice in $0.85 \% \mathrm{NaCl}$ solution, and the concentration was adjusted $10^{9}$ cells $/ \mathrm{ml}$. The bacterial suspensions were added $\mathbf{2 . 0} \% \mathrm{HCHO}$ in final concentration and kept at $37^{\circ} \mathrm{C}$ for $90 \mathrm{~min}$. After the treatment, the bacteria were washed twice in $0.85 \% \mathrm{NaCl}$ solution and suspended in original volume.

Preparation of vaccines other than bacteria : Zymozan type A, Gastric mucin (N. B. C.) Glycogen, Potato starch (Wako Co). Glycol chitin (Seikagaku Co.) were suspended in $0.05 \mathrm{M}$ phosphate buffer $\mathrm{pH} 7.2$ and concentration were adjusted $1 \mathrm{mg} / \mathrm{ml}$.

Immunization of the silkworm pupae : Pupae were immunized by injecting $5 \mu \mathrm{l}$ of the vaccines into the hemocoel. Protective immunity and batcericidal activity attained maximum levels $12 \mathrm{hrs}$. after the vaccination.

Collection of Sera: Immunized pupae were bled $12 \mathrm{hrs}$. after vaccination and each pool consisted of the serum from 25 pupae. In all cases, the hemolymph was centrifuged $1,000 \mathrm{~g}$ for $15 \mathrm{~min}$. and sera were stored at $-20^{\circ} \mathrm{C}$.

Bactericidal assay : The sera were diluted in $0.05 \mathrm{M}$ phosphate buffer pH 7.2. The final volume of diluted serum was $0.5 \mathrm{ml}$. The serum dilutions were added equal volumes of a bacterial suspension containing approximately $1.2 \times 10^{3}$ Escherichia coli (Umezawa strain) and were transfered to a water bath at $27^{\circ} \mathrm{C}$. A control was included in the diluent alone. After 30 minutes, $0.3 \mathrm{ml}$ samples from each tube were dropped onto nutrient agar plates. The colonies were counted, after $24 \mathrm{hrs}$. incubation at $37^{\circ} \mathrm{C}$. The end point of the titration was the highest dilution of serum which killed $50 \%$ or more of the inoculum.

Assay of serum lysozyme : A U. V. killed Micrococcus lysodeikticus were purchased from Seikagaku Kogyo Co. (Lot. No. $49 \sim 50$ ). The bacterial cells were suspended in $0.06 \mathrm{M}$ phosphate buffer $\mathrm{pH} 7.0$ and were kept at $4^{\circ} \mathrm{C}$ for overnight. The test sera were diluted to $10^{-2}$ in the same buffer solution. The assay procedure (Maekawa, 1965) was as follows : $2.5 \mathrm{ml}$ of M. Iysodeikticus suspension was added $1.0 \mathrm{ml}$ of phosphate buffer solution and finally 0.5 $\mathrm{ml}$ of sample was added. The mixture was kept at $27^{\circ} \mathrm{C}$ in a 
water bath for $10 \mathrm{~min}$. Then, the measurement of optical density were made on a Shimazu Spectronic 20 spectrophotometer at 540 m $\mu$. Relative activity of serum lysozyme was expresse as the reduction of optical density after 10 minutes incubation at $27^{\circ} \mathrm{C}$.

\section{Results}

\section{Effect of Bacterial Vaccines}

The effect of bacterial vaccines on the level of bactericidal activity for E. coli in the silkworm pupal hemolymph was studied by estimating the bactericidal titer at $27^{\circ} \mathrm{C}$. The bactericidal titers of sera against $E$. coli are shown in Table 1. All bacterial vaccines increased significantly the bactericidal activity in the silkworm pupal sera.

Table 1. Effect of bacterial vaccines on the production of bactericidal activity and serum lysozyme level in the silkworm pupal sera. ${ }^{1 !}$

\begin{tabular}{|c|c|c|}
\hline \multirow[t]{2}{*}{ Vaccine } & $\underset{\text { activity }}{\text { Bactericidal }}$ & \multirow[t]{2}{*}{$\begin{array}{l}\text { Lysozyme } \\
\text { activity" }\end{array}$} \\
\hline & 1 & \\
\hline P. aeruginosa PS 14 & 64 & .140 \\
\hline S. marcescens & 64 & .140 \\
\hline S. aureus $209 \mathrm{P}$ & 64 & .150 \\
\hline B. sotto ISHIWATA & 32 & .150 \\
\hline $0.85 \% \mathrm{NaCl}$ & $<1$ & .150 \\
\hline
\end{tabular}

1) Silkworm strain: Shûkô $\times$ Ryûhaku

2) Results expressed as reciprocal of bactericidal titer against $E$. coli.

${ }^{3)}$ Results expressed as decrease of optical density of M. lisodeikticus suspension at $540 \mathrm{~m} \mu$, during $10 \mathrm{~min}$. incubation at $27^{\circ} \mathrm{C}$.

However, the injection of saline was effectiveless on the production of enhanced bactericidal activity in the silkworm pupa. In this experiment, there are not much difference concerning to the effect of bacterial vaccines as a stimulant for enhanced bactericidal activity.

An effort was made to discover whether a correlation existed between the enhanced bactericidal activity against E. coli and the bacteriolytic activity against $M$. lysodeikticus (lysozyme activity) in the immunized silkworm pupal sera. The bacteriolytic activity against $M$. lysodeikticus in the silkworm pupal sera, was not affected by the vaccination with bacterial vaccines, i.e., the injection of bacterial vaccines did not change the serum lysozyme level. 


\section{Effect of vaccines other than bacterial cells}

An attempt was made to produce enhanced bactericidal activity in the silkworm pupal sera which was immunized by vaccines other than bacterial cells. The silkworm pupae were injected with the vaccines and they were bled $12 \mathrm{hrs}$. after vaccination. The sera were collected and bactericidal activity was assayed. The results are shown in Table 2.

Table 2. Effect of non-bacterial vaccines on the production of bactericidal activity and serum lysozyme level in the silkworm pupal sera ${ }^{1}$.

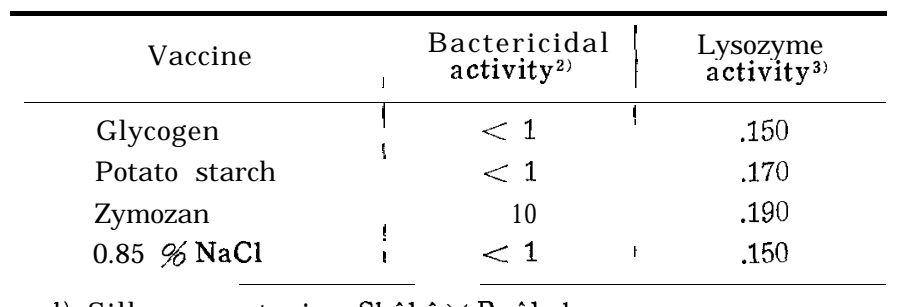

1) Silkworm strain: Shûkô $\times$ Ryûhaku

2) Results expressed as reciprocal of bactericidal titer against E.coli.

3) Results expressed as decrease of optical density of $\mathbf{M}$. lysodeikticus suspension at $540 \mathrm{~m} \mu$, during $10 \mathrm{~min}$. incubation at $27^{\circ} \mathrm{C}$.

Many of non-bacterial vaccines failed to produce enhanced bactericidal activity against $E$. coli. Only zymogan was slightly effective on the production of bactericidal actvity in the silkworm pupa. Also the effect of vaccines on the serum lysozyme level was assayed at the same time. The lysozyme activity in the silkworm pupal sera were not affected by the hemocoelic injection of the non-bacterial vaccines.

\section{Effect of non-bacterial vaccines on the level of serum lysozyme}

Although the injection of bacterial vaccines produced enhanced bactericidal activity in the silkworm pupal sera, the serum lysozyme level remained unchanged. Attempts were made to increase the serum lysozyme level and to find the correlation with the bactericidal activity in the silkworm pupal sera. The pupae were injected with the lysozyme substrate (Glycol chitin) and gastric mucin. The silkworm pupae were bled $12 \mathrm{hrs}$. after injection and the serum lysozyme activity was assayed. The results are shown in Table 3 . 
Table 3. Effect of non-bacterial vaccines on the level of serum lysozyme".

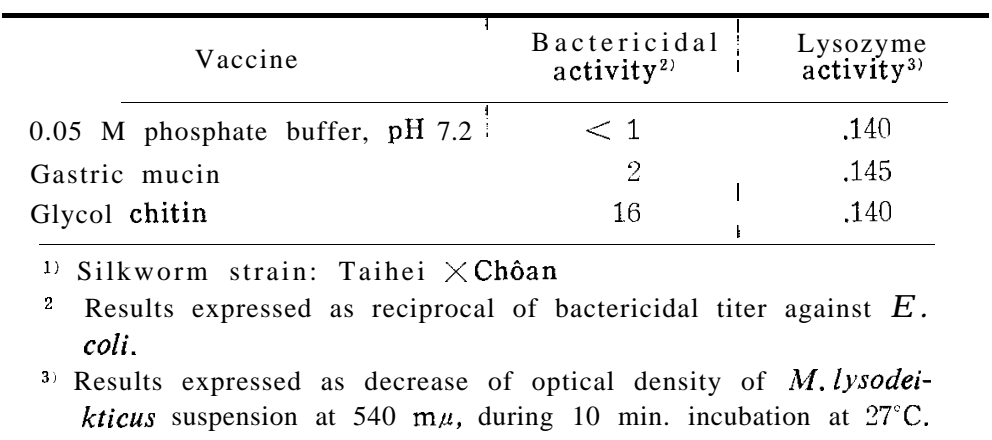

The injection of enzyme substrate did not affect the serum lysozyme level in the silkworm pupae. The bactericidal activity in the silkworm pupal sera was slightly increased after the injection of glycol chitin, but was not very strong. All vaccines which were used in this experiment, failed to produce an enhanced bacteriolytic activity against $M$. lysodeikticus in the silkworm pupal sera. The lysozyme level in the silkworm pupae was considered to be quite stable.

\section{Discussion}

Although non-specific bactericidal action of insects has evoked much interests since the early investigators have demonstrated by the vaccination, little attention has been paid to a study of bacterial inhibitory factors which relate to the bactericidal action in insect sera. In the present study, the relation between bactericidal titer and lysozyme level in the immunized silkworm pupal sera has been investigated.

Bacterial vaccines developed protective immunity in the silkworm pupae and also increased bactericidal activity of sera agianst $E$. coli, but not by non-bacterial vaccines (Kawarabata, 1970). As well as Gram-negative bacteria, the Gram-positive bacteria was able to enhance the bactericidal activity against $E$. coli by the vaccination. The titer of bactericidal activity which was produced by bacterial vaccines, did not differ considerably in the silkworm pupal sera. However, the bacteriolytic activity against $M$. lysodeikticus was not affected by the vaccination with bacterial vaccines.

The development of protective immunity in insects which were immunized by non-bacterial vaccines, was reported by early investigators (Ishimori \& Metalnikov, 1924; Zernoff, 1928). An attempt was 
made to produce enhanced bactericidal activity in the insect by the vaccination with non-bacterial vaccines. In some case, the slight increase of bactericidal activity in the silkworm pupal sera was observed. Removal of possible contaminating bacterial cells is one of the important problems of "non-bacterial" vaccines. There is a possible contamination of bacterial cells, in the case of non-bacterial vaccines. However, the resulted bactericidal titer was not so much than that of the bacterial vaccines.

Although, Chadwick (1970) reported that lysozyme concentration of hemolymph increased when Galleria mellonella larvae were injected with bacterial vaccine. It was unsuccessful to stimulate the production of serum lysozyme in the silkworm pupa. The lysozyme level in the silkworm pupal sera was considered to be quite stable.

Hink \& Briggs (1968) reported the hemolymph bactericidal factors in Galleria mellonella and they were not proteins. The lysozyme activity is also present in Galleria and the silkworm serum lysozyme level is generally higher than that of Galleria (Kawarabata, Unpublished data). Both the bactericidal activity and the lysozyme activity of immunized silkworm sera have been found in the same fraction by the gel-filtration on Sephadex G-100 (Kawarabata, 1970). Gingrich (1964) reported the bacteriolytic substances on the milkweed bugs. However, the its relation to serum lysozyme are not clear. Serum lysozyme and its relation to non-specific antibody-complement mediated bactericidal activity in manmalian sera were studied (Salton, 1957; Skarnes \& Watson, 1957). Schwab \& Reeves (1966) were not able to find consistent correlation between nonspecific bactericidal titer and serum lysozyme level in poikilothermic and homeothermic vertebrates. They also pointed out that lysozyme may not be responsible for the bactericidal titer in manmalian sera, although it may lyse bacteria which have been killed by complement and antibody.

The bactericidal system which is not mediated by antibody-complement system have been present in insects. It may suggest that the silkworm serum lysozyme may not be responsible for the bactericidal titer of the serum, although it may help the bactericidal and bacteriolytic action in the hemolymph.

\section{References}

Briggs, J. D. (1958) Humoral immunity in Lepidopterous larvae. J. Expt. Zool. $138: 155-188$.

Chadwick, J. S. (1970) Belation of lysozyme concentration to aquired immunity against Pseudomonas aeruginosa in Galleria mellonella. J. Invertebr. Pathol. 15, 455-456. 
Gringrich, R. E. (1964) Acquired humoral immune response of the large milkweed bug, Oncopeltus fasciatus (Dallas), to injected materials. J. Insect Physiol. 10: 179-194.

Glaser, R. W. (1918) On the existence of immunity principles in insects. Psyche 25: $39-46$.

Hink, W. F. \& J. D. Briggs (1968) Bactericidal factors in hemolymph from normal and immune wax moth Iarvae, Galleria mellonella, J. Insect Physiol. 14: 1025-1034.

Ishimori, N. \&S. Metalnikov (1924) Immunisation de la chenille de Galleria mellonella par des substances non spécifiques. Compt. rend. 178: 2136-2138.

Kawarabata, T. (1970) Studies of an acquired resistance on microbial infections in the silkworm (Bombyx mori L.). Sci. Bull. Fac. Agr. Kyushu Univ. 24: 231 -254 (In Japnese).

Maekawa, K. (1965) Methods in biochemistry. Kagakuno Ryoiki, Nankodo (in Japanese).

Salton, M. R. J. (1957) The properties of lysozyme and its action on microorganisms. Bacteriol. Rev. 21: 82-99.

Schwab, G. E. \& P. R. Reevs (1966) Comparison of the bactericidal activity of different vertebrate sera. J. Bacteriol. 91: 106-112.

Skarnes, R. C. \& D. W. Watson (1957) Antimicrobial factors of normal tissues and fluids. Bacteriol. Rev. 21: 273-294.

Stephens, J. M. (1962) Bactericidal activity of the blood of actively immunized wax moth larvae. Can. J. Microbiol. 8: 491-499.

Stephens, J. M. \& J. H. Marshal (1962) Some properties of an immune factor isolated from the blood of actively immunized wax moth larvae. Can. J. Microbiol. 8 : 719-725.

Zernoff, V. (1928) Sur la nature de l'immunité passive chez les chenilles de Galleria mellonella. Compt. rend. soc. biol. 99: 315-317.

(1931) Les bactérilysines chez les insectes. Ann. Inst. Pasteur 46 : 565-571. 